кандидат педагогічних наук, старший викладач (Житомирський державний технологічний університет) olena_1409@ukr.net

ORCID : $0 \odot \odot \odot-\odot \odot \odot 2-1279-1888$

\title{
ОСОБЛИВОСТІ ТЕХНОЛОГІЇ ФОРМУВАННЯ ЕКОЛОГІЧНОЇ КОМПЕТЕНТНОСТІ МАЙБУТНІХ ГІРНИЧИХ ІНЖЕНЕРІВ
}

\begin{abstract}
В статті розглянуто та проаналізовано актуальні ідеї застосування освітніх технологій навчання та викладання у вищій школі. Обгрунтовано запровадження педагогічної технології формування екологічної компетентності майбутніх гірничих інженерів у процесі професійної підготовки. Розкрито роль дисииплін гуманітарного, природничого та ииклу професійного спрямування у формуванні складових екологічної компетентності. Визначено провідні форми та методи навчальної роботи, щчо сприяють формуванню екологічної компетентності фахівияів напряму "Гірництвво".
\end{abstract}

Ключові слова: технологія, педагогічна технологія, природничі дисципліни, гірничий інженер.

Постановка проблеми. Питання захисту довкілля дедалі гостріше постають перед світовою спільнотою. Про це засвідчують розроблені та прийняті на початку XXI століття міжнародні документи, серед яких можна відзначити такі: Стокгольмська конвенція про стійкі органічні забруднювачі (2001р.), Паризька хартія про зміну клімату (2015 р.). Крім того, у вересні 2015 року відбувся Саміт ООН для прийняття Порядку денного в галузі розвитку на період після 2015 року. В рамках останнього було ухвалено Цілі сталого розвитку до 2030 року, серед яких були й питання екологічної безпеки. Однак, розв'язання екологічних проблем неможливе без якісної екологічної підготовки, особливо для фахівців технічного спрямування, зокрема напряму "Гірництво", професійна діяльність яких безпосередньо пов'язана 3 порушенням навколишнього природного середовища. Це потребує розробки та запровадження освітніх технологій, які б забезпечували можливість знаходження оптимальних шляхів формування екологічної компетентності майбутніх фахівців. Проте майбутні гірничі інженери, незважаючи на певний обсяг здобутих знань та практичних умінь, часто виявляються неспроможними реалізувати ідеї та принципи екологічної поведінки у своїй професійній діяльності. Зазначене свідчить про недосконалість традиційної технології формування екологічної компетентності та іiі складових, як показників якості професійної компетентності. Саме освітні технології дозволяють отримати відповідь на питання: як, яким чином передати нові знання та створити умови для успішного досягнення визначених результатів.

Аналіз останніх досліджень та публікацій. Питанням освітніх технологій присвятили свої дослідження низка закордонних та вітчизняних вчених зокрема: Б. Блум, Дж. Брунер, В. П. Беспалько, М.В.Кларіна, П. Мітчел, К. Річмонд та інші. Проблемі компетентнісної особистісно-зорієнтованої освіти присвячені роботи І. А. Зязюна, О. Б. Спішева, В. І. Журавльова, С. І. Подмазіна, О. М. Пєхоти, Г. К. Селевка, В.Сєрікова, С. О. Сисоєвої, Н. С. Щуркової тощо.

Різноманітні аспекти щодо питання формування екологічної компетентності фахівців висвітлювали: О. В. Гуренкова, Я. О. Логвінова, Т. Ф. Лукашенко, С. М. Лутковська, Н. Ю. Олійник, Л. М. Титаренко, А. Л. Хрипунова, Н. М. Черновол та ін.

Однак, поза увагою дослідників залишилася проблема ефективної технології формування екологічної компетентності майбутніх гірничих інженерів, яка потребує залучення нових підходів до їі вирішення, 3 огляду на майбутню професійну діяльність гірничих інженерів.

Метою цієї статті, як складової нашого дослідження, $\epsilon$ - аналіз та висвітлення змісту технології формування екологічної компетентності майбутніх гірничих інженерів у процесі професійної підготовки.

Методи дослідження. Наукові методи аналізу, синтезу, спостереження та узагальнення були використані для розробки технології формування екологічної компетентності та іiї складових у майбутніх гірничих інженерів.

Виклад основного матеріалу. Педагогічна технологія, на думку М. В. Кларіна, означає системну сукупність і порядок функціонування всіх особистісних інструментів і методологічних засобів, які використовуються для досягнення педагогічних цілей [1].

Цінною в контексті нашого дослідження є думка В. Л. Моложавенко, що в своїх працях розглядає технологію на основі компетентнісного підходу як цілеспрямоване організоване конструювання освітнього простору, спрямоване на гарантоване досягнення запланованих результатів у відповідності 3 освітніми цілями [2: 82].

Слушною є думка, яку висловлюють В. О. Сластьонін, Н. Г. Руденко, що розглядають педагогічну технологію як впорядковану сукупність дій, операцій і процедур, які забезпечують досягнення прогнозованого результату в умовах динамічного освітнього процесу [3]. 
Призначення освітньої технології І. М. Дичківська вбачає у вирішенні стратегічних для освіти завдань: проектування цілей, основних етапів, способів, організаційних форм освітньо-виховного процесу [4: 27].

3 нашого погляду технологія формування екологічної компетентності майбутніх гірничих інженерів це сукупність дій, операцій, процедур, які забезпечують формування екологічно компетентного фахівця 3 напряму гірництво. Проблема формування екологічної компетентності майбутніх гірничих інженерів $€$ багатокомпонентною і розгляд всіх ii складових створює цілісну картину професійної готовності студентів гірничих спеціальностей до майбутньої діяльності. Отже, екологічна компетентність $\epsilon$ основним чинником успішної екологічної діяльності.

В контексті нашого дослідження технологія формування екологічної компетентності майбутнього гірничого інженера - це технологічна модель взаємодії викладачів і студентів у процесі навчання, що включає планування, організацію та проведення особистісно зорієнтованого реального процесу за умови забезпечення комфортності для усіх суб’єктів педагогічної діяльності.

Недоліком сучасної освіти залишаються недостатні вміння студентів "вільно використовувати здобуті знання для розв'язання практичних завдань, аналізу нестандартних ситуацій" [5: 63]. На нашу думку, цю проблему можна розв'язати використовуючи особистісно-орієнтовану технологію навчання у ВНЗ. Зазначена технологія $\epsilon$ альтернативою традиційній, яка спрямована на забезпечення засвоєння студентами ЗУН не лише на рівні відтворення, а й критичного мислення, вміння відстоювати власну думку, формування свідомого ставлення до розгляду будь-якої проблеми, створення умов для використання особистого досвіду й одержаних раніше знань для засвоєння нових.

Розроблена нами особистісно-орієнтована технологія формування екологічної компетентності майбутнього гірничого інженера допоможе особистості пізнати себе, самовизначитись i самореалізуватись та спрямована на:

- $\quad$ розвиток індивідуальних здібностей кожного студента та максимальне виявлення й використання індивідуального досвіду екологічної діяльності;

- спонукання та стимулювання внутрішньої потреби до екологічно спрямованої поведінки;

- актуалізацію вже набутих екологічних знань та вмінь для подальшого засвоєння нового навчального матеріалу;

- $\quad$ розвиток здібності до систематичного аналізу можливих варіантів виконання завдань 3 метою прийняття екологічно виваженого рішення;

- $\quad$ здатності до самоконтролю під час виконання самостійної роботи.

Педагогічне середовище обумовлює центральний елемент технології, що об’єднує мету, зміст, результат і перспективи формування екологічної компетентності та забезпечує їх взаємодію 3 іншими елементами екологічної підготовки.

Технологія реалізовувалася в декілька етапів: мотиваційно-орієнтаційний, когнітивно-інтеграційний, результативно-оцінний, для кожного з яких нами визначено цілі, зміст, форми та засоби.

Мотиваційно-орієнтаційний етап, який має на меті формування мотиваційного та аксіологічного компонентів екологічної компетентності, розкриває цілі та мотиви суб'єктів навчального процесу та завдання, необхідні для досягнення поставлених цілей.

3 метою підвищення рівня екологічної компетентності викладачів ВНЗ нами були проведені тренінги серед викладачів: "Що ми знаємо про екологічну компетентність?", "Екологічна компетентність гірничого інженера", "Екологічна компетентність, як складова професійної компетентності". Це сприяло єднанню думки педагогів відносно екологічної освіти майбутнього фахівця. Крім того, викладачі були єдині в тому, що за формування екологічної компетентності відповідальними $\epsilon$, як викладачі, так і сім'я і суспільство.

Екологічна підготовка студентів напряму "Гірництво" відбувалась у процесі вивчення дисциплін гуманітарного (право - 81 год., історія - 108 год., філософія - 162 год.) та природничо-наукового (хімія 162 год., екологія - 81 год.) циклів. Так при викладанні природничих наук, зокрема хімії та екології, які вивчаються на I курсі, знаходять своє відображення сучасні тенденції формування екологічних знань на всіх рівнях навчання. Враховуючи, що ці курси найбільш близькі до проблем довкілля, то основні екологічні знання і системи понять вводяться саме в них.

Дисципліни гуманітарного циклу, зокрема філософія, яка вивчається на II курсі, має на меті забезпечити освоєння філософії як специфічного освоєння дійсності, як науки та світогляду, найважливішими проблемами яких виступають відносини "людина-світ".

Основними завданнями технології формування екологічної компетентності майбутнього гірничого інженера на цьому етапі були такі:

- засвоєння екологічної термінології, знання та дотримання природоохоронного законодавства;

- формування екологічної компетентності майбутніх гірничих інженерів.

Технологія формування екологічної компетентності майбутнього гірничого інженера передбачала розробку цілей навчання у пізнавальній сфері, що спрямовані на організацію системи норм та правил 
ставлення до довкілля, умінь та навичок щодо вивчення та охорони навколишнього середовища на основі нових принципів взаємодії "людина - суспільство - природа". Крім того, на цьому етапі відбувається формування професійної екологічно вмотивованої індивідуальності майбутнього гірничого інженера, для якого екологічні цінності є пріоритетними.

На когнітивно-операційному етапі реалізовано змістовий компонент технології, який включав теоретичну складову, в процесі якої на заняттях звертається увага на екологічні проблеми та практичну частину, де увага приділяється вирішенню екологічних завдань практичного характеру.

Теоретична підготовка здійснювалась у процесі засвоєння дисциплін гуманітарної та соціальноекономічної, природничо-наукової, загальноінженерної та професійно-практичної підготовки (безпека життєдіяльності - 108 год., основи гірничого виробництва - 108 год., основи охорони праці - 54 год., переробка і збагачення корисних копалин - 108 год., екологія гірничого виробництва та каменеобробки 81 год. та інших) та факультативного курсу "Особливості формування екологічної компетентності майбутніх гірничих інженерів".

Практична підготовка забезпечувалася при виконанні курсових проектів, а саме 3 "Основ проектування гірничих підприємств" (III курс - 108 год.) та під час проходження навчальних практик (702 год.): навчальна практика (геологічна) - 162 год., навчально-ознайомча практика (геодезична) 162 год., виробнича практика - 162 год. та переддипломна практика - 216 год.

В результаті тісної взаємодії студента і викладача, майбутні гірничі інженери здобувають нові знання та осягають сутність майбутньої професії, зокрема ії екологічні складові.

Когнітивно-операційний (інтеграційний) етап мав на меті цілеспрямоване формування когнітивного компонента екологічної компетентності майбутнього гірничого інженера, яке пов'язане з організацією процесу засвоєння студентами екологічних знань та їх інтегрування в дисципліни професійного спрямування, а отже і в майбутню професійну діяльність. При цьому, на нашу думку, слід застосовувати форми та методи, які грунтуючись на сприйнятті екологічної інформації забезпечили розвиток екологічного мислення та формування екологічного світогляду. Тому проблемні лекції, лекції-дискусії та лекції-аналіз набули широкого застосування на когнітивно-інтеграційному етапі. Однак у всіх випадках 3 метою покращення ефективності засвоєння матеріалу їх необхідно доповнити за допомогою таких форм організації навчального процесу як семінарські заняття, лабораторні та практичні роботи, а також тренінги та позааудиторні форми роботи викладачів та студентів. Крім того, застосування сучасних освітніх технологій таких як ділові ігри, метод проектів та інформаційні технології сприятимуть, на нашу думку, формуванню екологічної компетентності фахівців створюючи позитивну мотивацію для вивчення матеріалу.

Центральним на формувальному етапі експериментального дослідження був факультативний курс "Особливості формування екологічної компетентності майбутніх гірничих інженерів", який узгоджений 3 функціонально-структурними елементами моделі та спрямований на формування технічно орієнтованих екологічних знань студентів напряму "Гірництво". Факультативний курс, який вивчався на 1 курсі, інтегрував екологічні знання в професійну підготовку та вносив корекцію в навчальний процес підготовки майбутніх гірничих інженерів. Цей курс передбачав 54 години вивчення дисципліни, 3 яких лекції - 12, семінарські заняття - 8, лабораторні - 8, самостійна робота та індивідуальні завдання 26 годин.

Курс лекцій містив такі теми: Сучасна система екологічної освіти у вищих технічних навчальних закладах; Сутність та зміст екологічної підготовки фахівців з гірництва; Сучасні вимоги до формування екологічної компетентності; Характеристика впливу гірничовидобувної та гірничопереробної промисловості на довкілля; Закономірності та фактори міграції хімічних елементів; Проблеми раціонального природокористування при розробці родовищ корисних копалин. Лекційний курс був спрямований на розвиток критичного мислення студентів, тому лекції переважно були проблемного характеру. Центральною темою вивчення цього курсу було "Проблеми раціонального природокористування при розробці родовищ корисних копалин". Факультативний курс складається 3 двох частин: загальні теоретичні основи екологічної освіти та вища екологічна освіта України. Загальні теоретичні основи екологічної освіти містить основні концептуальні положення технології особистісноорієнтованого навчання, а також сутність та зміст екологічної підготовки фахівців з гірництва. Друга частина курсу: "Вища екологічна освіта України", дає майбутнім гірничим інженерам можливість краще зрозуміти важливість та необхідність раціонального природокористування та енергоощадження в сучасних умовах господарювання.

Під час проведення факультативного курсу для активації пізнавальної діяльності студентів нами проведено такі проблемні лекції: "Характеристика впливу гірничовидобувної та гірничопереробної промисловості на довкілля", "Закономірності та фактори міграції хімічних елементів", "Проблеми раціонального природокористування при розробці родовищ корисних копалин". При конструюванні кожної лекції нами визначаються проблеми для обговорення та основні протиріччя, які потрібно вирішити. Так, наприклад, основною проблемою при проведені лекції "Проблеми раціонального 
природокористування при розробці родовищ корисних копалин" $є$ охорона і рекультивація земель, оскільки в процесі розробки родовищ досить часто втрачається значна частина верхнього найбільш родючого шару грунту. В процесі розв'язання проблеми на лекції потрібно послідовно розглянути такі питання: біологічні аспекти охорони природи, вплив стану грунту на здоров'я населення, охорона i рекультивація земель, правові та економічні аспекти охорони навколишнього природного середовища. Розгляд зазначених питань впливу гірничовидобувної діяльності на стан земель приводить до висновку, що питання раціонального природокористування є життєво важливим чинником екологічної стабільності та сталого розвитку цивілізації. Організація самостійної роботи студентів пропонує такі теми рефератів: "Міжнародні ресурси і проблеми, які виникають при їх використанні", "Правоохоронне забезпечення екологічного контролю", "Органи управління, охорони і нагляду 3 охорони природи, їх функції", "Економічна цінність природних ресурсів України", "Основні напрями розвитку маловідходних i ресурсозберігаючих технологій", "Роль міжнародного співробітництва у вирішенні екологічних проблем".

Когнітивний компонент екологічної компетентності передбачає не лише здобуття екологічних знань, а й формування екологічного мислення майбутнього гірничого інженера. Студенти мають навчитися аналізувати, порівнювати, виділяти та класифікувати екологічні небезпеки гірничовидобувного та гірничопереробного комплексу. Майбутні фахівці мають прогнозувати вплив техногенних чинників на стан довкілля, моделювати інженерні заходи із захисту навколишнього середовища, оцінювати екологічну ефективність запроваджених заходів. На нашу думку, важливим елементом організації практичної екологічно спрямованої діяльності та високого рівня засвоєння знань в межах реалізації факультативного курсу є семінарські та практичні заняття. На відміну від лекцій, які закладають основи наукових знань і слугують підгрунтям для поглиблення і систематизації знань, семінарські та практичні заняття мають на меті розширити, деталізувати та закріпити екологічні знання. Крім того вони сприяють формуванню та закріпленню екологічно спрямованих умінь та навичок. Важливою формою роботи $\epsilon$ лабораторні заняття, проведення яких мало на меті закріпити знання отримані при вивченні лекційного курсу, а також на семінарських та практичних заняттях. На лабораторних заняттях відбувається формування екологічних умінь та навичок, що $є$ важливою складовою екологічної поведінки, а отже відбувається формування діяльнісного компоненту екологічної компетентності.

Враховуючи цей факт, на допомогу студентам, нами були розроблені методичні рекомендації до вивчення факультативного курсу "Особливості формування екологічної компетентності майбутніх гірничих інженерів", що містять теоретичні відомості до кожної із запланованих тем. Крім того застосовуються також інші форми самостійної роботи студентів під керівництвом викладача, які реалізуються у вигляді консультацій, творчих завдань, тощо.

В експериментальних групах окрім запропонованого факультативного курсу і технології, було впроваджено спеціальні завдання у системі виробничих практик, виконання яких слід відобразити у щоденнику та у звіті з практики. Навчальний процес в експериментальних групах проводився на основі єдності педагогічних принципів та принципів екологічної освіти: цілісності, неперервності, інтегративності, доступності, науковості та системності. Студенти проходили виробничі практики на підприємствах гірничовидобувного та гірничопереробного комплексу Житомирської області. Ключовим аспектом концепції екологічної освіти на даному етапі $\epsilon$ формування екологічної культури та збереження здоров'я фахівця. Під час проходження практики студентам пропонувалося на основі доступної документації та грунтуючись також на власних спостереженнях висловити та обгрунтувати власну думку щодо екологічної безпеки виробництва та збереження здоров'я працівників. Студенти мали також запропонувати комплекс заходів, які були покликані сприяти зменшенню техногенного навантаження виробництва на довкілля.

На заключному, результативно-оиіночному етапі відбувалося оволодіння екологічною компетентністю, що характеризувалося сформованістю всіх компонентів екологічної компетентності майбутнього гірничого інженера та проявлялося під час участі студентів у різноманітних позааудиторних заходах і акціях екологічного характеру.

Важливими для формування екологічної компетентності майбутнього гірничого інженера, були також різноманітні позааудиторні форми роботи, особливістю яких є те, що вони грунтуються на засадах добровільності та задоволення пізнавальних інтересів і потреб студентів. На нашу думку, для організації практичної екологічно спрямованої діяльності, як на побутовому, так і на професійному рівнях одночасно $з$ аудиторними формами роботи ефективним $є$ залучення студентів до різноманітних екологічних заходів, акцій та екскурсій, які сприятимуть формуванню екологічної активності особистості у вирішенні екологічних проблем. Зокрема, студенти експериментальних груп брали участь у таких природоохоронних акціях, як: "Малим річкам - чисту воду", "Посади дерево", "Зелена планета", "Чисте місто", природоохоронних акціях до Дня довкілля тощо. Крім того нами проводилась низка позааудиторних заходів на екологічну тематику: конкурс плакатів "Майбутнє планети в наших руках", ігри типу "Що? Де? Коли?", вікторини "Чисте довкілля - здорове покоління", "Зелена аптека" тощо. 
Важливою складовою у формуванні екологічної компетентності майбутніх гірничих інженерів $\epsilon$ навчальні екскурсї, які забезпечують формування мотиваційного, когнітивного, діяльнісного та аксіологічного компонентів екологічної компетентності. Для студентів експериментальних груп проводились ознайомчі екскурсії на виробничі об'єкти міста та області. Так, з метою ознайомлення студентів з природними багатствами Житомирщини була організована екскурсія до "Музею коштовного та декоративного каміння", що в смт. Володарськ-Волинський. Також студенти відвідали "Новоберезівський", "Давидівський", "Лезніківський" кар'єри, де під час екскурсій знайомилися 3 виробничими та технологічними процесами, а також визначали чинники, що впливають на якість оточуючого середовища, рівень шкідливості виробництва та потенційні загрози для здоров'я людини, пізнавали екологічну ситуацію рідного краю, вчилися аналізувати та встановлювати причинно-наслідкові зв'язки екологічних проблем, прогнозувати екологічні наслідки антропогенного та техногенного впливу, давати оцінку екологічним взаємодіям в контексті концепції сталого розвитку. При цьому особлива увага приділялася оформленню результатів екскурсії, які студенти могли представити у вигляді презентацій, доповідей тощо. Цінність екскурсій полягає в тому, що навчання під час екскурсій відбувається при безпосередньому сприйнятті об'єктів, що спостерігаються, зв'язку навчання з життям, поясненні теоретичного та практичного значення досліджуваних об'єктів, реалізації міжпредметних зв’язків.

Постійний моніторинг, пілотажні зрізи надали нам можливість зробити висновки, що найбільш ефективними є такі форми семінарських та практичних занять як: семінар-дискусія "Визначення та вивчення мотивів вибору студентами майбутньої професії", семінар з елементами "мозкового штурму" "Розробка моделі екологічної компетентності майбутніх гірничих інженерів", тематичні заняття 3 використанням методу "аналізу ситуацій" "Визначення внутрішніх факторів фізико-хімічної міграції хімічних елементів" та "круглого столу" "Мінеральні ресурси та технофільність хімічних елементів".

Результати студентів оцінювалися за кредитно-модульною системою навчання за 100 - бальною шкалою. Протягом всього часу вивчення факультативного курсу студенту пропонувалося набрати певну кількість балів, які мали відображати повноту засвоєння екологічних знань та сформованості екологічних умінь та навичок. В процесі вивчення факультативного курсу застосовується поточний контроль, модульний контроль та підсумковий контроль знань студентів. Об'єктом оцінювання знань студентів $є$ програмний матеріал різного рівня складності, засвоєння якого здійснюється під час поточного та підсумкового контролю.

Висновок. Впровадження особистісно-орієнтованої технології у навчальний процес 3 метою формування екологічної компетентності дозволяє:

- спроектувати навчальну діяльність, максимально враховуючи індивідуальні здібності й можливості суб’ єктів і гарантувати досягнення мети.

- розроблена технологія забезпечує викладання навчального матеріалу з метою, як розширення обсягу екологічних знань, так і постійного перетворення їх в суб’єктний досвід кожного студента;

- стимулює студентів до самоосвіти, саморозвитку та самовираження під час оволодіння новими знаннями та формує внутрішню потребу до екологічної поведінки;

- адаптується до особистісних особливостей студента, його індивідуальних властивостей, які впливають на навчальну діяльність;

- гнучкість технології дозволяє організувати навчальний матеріал так, щоб студент мав можливість вибору при виконанні завдань екологічного характеру і використанні найбільш значущих для нього способів опрацювання навчального матеріалу;

- запропонована технологія дозволяє контролювати й оцінювати не лише результат, а й зміни особистості студента, які відбулись у процесі формування екологічної компетентності.

Реалізація запропонованої технології потребує подальшого дослідження зокрема в напрямі порівняльного аналізу екологічної підготовки фахівців освітніх рівнів бакалавр і магістр 3 напряму "Гірництво".

\section{СПИСОК ВИКОРИСТАНИХ ДЖЕРЕЛ ТА ЛІТЕРАТУРИ}

1. Кларин М. В. Педагогические технологии в учебном процессе (Анализ зарубежного опыта) / М. В. Кларин. М.: Знания, 1989. -75 с.

2. Моложавенко В. Л. Компетентностная модель специалиста - выпускника вуза как основа проектирования технологии компетентностного подхода к образованию / В. Л. Моложавенко // Вестник университета Российской академии образования. - 2008. - № 3 (41). - С. 81-85.

3. Сластенин В. А. О современных подходах к подготовке учителя / В. А. Сластенин, Н. Г. Руденко // Педагог. - 1997. - № 3 .

4. Дичківська І. М. Інноваційні педагогічні технології : [навч. посібник] / І. М. Дичківська - К. : Академвидав, 2004. $-334 \mathrm{c}$.

5. Фасоля А. Азбука особистісно-орієнтованого навчання / А. Фасоля // Українська мова і література в середніх школах, гімназіях, ліцеях та колегіумах. - 2004. - № 4. - С. 62-67. 


\section{REFERENCES (TRASLATED \& TRANSLITERATED)}

1. Klarin M. V. Pedagogicheskiie tekhnologii $\mathrm{v}$ uchebnom protsesse (Analiz zarubezhnogo opyta) [Pedagogical Technologies in the Educational Process (Analysis of Foreign Experience)] / M. V. Klarin. - M. : Znaniia, 1989. $75 \mathrm{~s}$.

2. Molozhavenko V. L. Kompetentnostnaia model' spetsialista - vypusknika vuza kak osnova proektirovaniia tekhnologii kompetentnostnogo podkhoda k obrazovaniyu [Competence Model of a Graduate Specialist as a Basis for Designing a Technology for a Competence Approach to education] / V. L. Molozhavenko // Vestnik universiteta Rossiiskoi akademii obrazovaniia [Bulletin of the University of the Russian Academy of Education]. - 2008. - № 3 (41). - S. 81-85.

3. Slastenin V. A. O sovremennykh podkhodakh $\mathrm{k}$ podgotovke uchitelya [On Modern Approaches to Teacher's Training ] / V. A. Slastenin, N. G. Rudenko // Pedagog. - 1997. - № 3.

4. Dychkivska I. M. Innovatsiini pedahohichni tekhnolohii [Innovative Pedagogical Technologies] : [navch. posibnyk] / I. M. Dychkivska - K. : Akademvydav, 2004. - 334 s.

5. Fasolia A. Azbuka osobystisno-oriyentovanoho navchannia [The ABC of Personality-Oriented Learning] / A. Fasolia // Ukrayins'ka mova i literatura v serednikh shkolakh, himnaziiakh, litseiakh ta kolehiumakh [Ukrainian Language and Literature at Secondary Schools, Gymnasiums, Lyceums and Colleges]. - 2004. - № 4. S. 62-67.

Герасимчук Е. Л. Особенности технологии формирования экологической компетентности будущих горных инженеров.

В статье рассмотрено и проанализировано актуальные идеи использования образовательных технологий обучения и преподавания в высшей школе. Обосновано введение педагогической технологии формирования экологической компетентности будущчих горных инженеров в процессе

профессиональной подготовки. Раскрыта роль дисциплин гуманитарного, естественного и цикл профессионального направления в формировании составляющих экологической компетентности. Определены ведущие формы и методы учебной работы, способствующие формированию экологической компетентности специалистов направления "Горное дело".

Ключевые слова: технология, педагогическая технология, естественные дисциплины, горный инженер.

\section{Herasymchuk O. L. Peculiarities of Forming Ecological Competence among Future Mining Engineers.}

Sharp ecological issues require qualitative ecological education that provides the formation of ecological world outlook among future specialists who will be able to carry out their future professional activities taking into account the possibilities of nature. This issue is of urgent importance especially for technical specialists, in particular for the field of "Mining" where specialists deal with the breach of environment. This needs the development and introduction of education technologies, which would provide finding the optimal ways of forming ecological competence among future specialists.

The article describes and analyzes the actual ideas of applying educational technologies of training and teaching in a higher educational establishment. The scientific methods of analysis, synthesis, observation and generalization are used for the development of technology of forming ecological competence and its constituents among future mining engineers. The author substantiates the introduction of pedagogical technology of forming ecological competence among future mining engineers in the process of their professional training. The paper examines the main stages of the technology realization, namely, motivational and orientation, cognitive and integration, resulted and estimation. According to every stage the paper determines the goals, contents, forms and means of the technology of forming ecological competence of future specialists. The author shows the role of humanitarian, natural, and professional oriented sciences for forming the constituent parts of ecological competence. The paper determines the leading training forms and methods that influence the formation of ecological competence of specialists in the field of "Mining".

Key words: technology, pedagogical technology, natural sciences, mining engineer. 